\title{
Employer-employee relations and employee engagement in a tertiary institution in Benin- City, Edo State
}

Chukwuyem Joel Arimie

Department of Political Science and Public Administration, Benson Idahosa University, Nigeria jarimie@biu.edu.ng

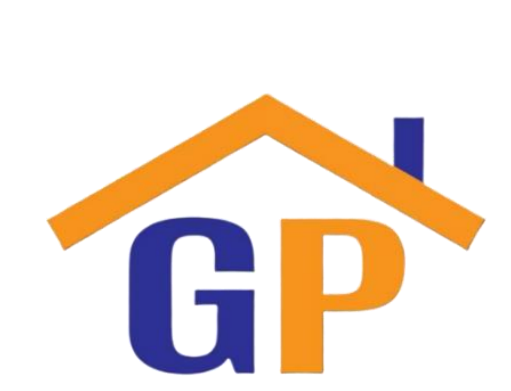

Article History

Received on 7 August 2020

$1^{\text {st }}$ Revision on 20 August 2020

$2^{\text {nd }}$ Revision on 25 August 2020

Accepted on 26 August 2020

\begin{abstract}
Purpose: This study aimed to explore the relationship between employer-employee relations and employee engagement in a tertiary institution in Edo State.

Research methodology: Semi-structured interviews were conducted on a cross-section of management staff, heads of department, and units in the University. A descriptive method was adopted for data analysis.
\end{abstract}

Results: The results of this study revealed that employee engagement is a by-product of employer-employee relations and the quality of the relationship is one of the most critical factors that drive engagement and satisfaction of employees.

Limitations: The challenge was the inadequate number of respondents interviewed due to time constraint.

Contribution: The study provided insight into the so called "soft aspect" of an organization and the way people relate with one another, and advocated the need for employers, managers, and supervisors in organizations to recognize the emotional composite of an employee, and the creation of a healthy relationship that would meet the employee' emotional needs.

Keywords: Effective employer-employee relations, Engagement, Psychological needs, Productivity

How to cite: Arimie, Chukwuyem Joel. (2019). Employeremployee relations and employee engagement in a tertiary institution in Benin-City, Edo State. Annals of Management and Organization Research, 1(1), 9-24.

\section{Introduction}

In today's competitive world, the key to organizational success relies on employees. It is no gainsaying that the invaluable role of employees is increasingly gaining wider attention amongst employers. Steve Jobs (2008), who was the co-founder and Chief Executive Officer of Apple Inc. gave credence to innovations at Apple to employees. He asserts that innovation has nothing to do with money, but it's about people. His recognition of the contribution of the employees in developing innovative products geared him to foster a thriving employer-employee relationship, which inspired a culture of hard work and creativity.

Similarly, Mary Kay Ash (2008) founder of a billion dollars Cosmetics Company describes employees as an organization's greatest assets. She opined that an organization is only good as the employees it can retain. Equally, an American Industrialist, Andrew Carnegie as quoted by Sharma M.P. Sadana B.L \& Harpret K. (2013) attributed employees as the key that unlocks the doors of an organization. This indicates that employees are the resources that make the organization, and the recognition of this assertion culminates in the creation of a healthy employer/employee relations.

The existence of a healthy relationship between the employers and the employees in an organization occupies a very paramount position in the realization of organizational goals and objectives. According to Schreiner (2019), effective management of employer-employee relations is 
vital to organizational success as healthy relationships can bring about employee engagement and even enhanced employee performance. This is important because the relationship between the employer and the employee is one of mutual reliance. The employer depends on the employees to execute their functions, to ensure the smooth running of the organization. Conversely, the employees depend upon the employer to compensate then financially and create an enabling environment that meets their psychological needs.

Employer-employee relation as pointed out by Chand (2016:3) is the harmonious atmosphere in which both parties practice the act of working in such a way that they effectively communicate and work pleasantly, thereby recognizing each other's needs and value leading to enhanced motivation and morale of the employees. Research has revealed that there is a relationship between effective employeremployee relations and employee engagement. According to Sheaheen (2017:391) when employers create an enabling environment for employees to be treated with respect and feel at home in discharging their responsibility, it will instill a positive psychological attitude towards the organization, which enhances employee engagement. Osborne and Mohamad (2017: 51) added that lower employee engagement in an organization can be as a result of the poor employer-employee relations, given that, he stressed the need for employers to create an enabling working environment for their employees. However, the dearth of qualitative research to support the correlation between employer-employee relations and employee engagement in the Nigerian context advocated the need for this study. The paper is divided into five sessions. Apart from session one which is the introduction, section two covers the review of literature on the concept of discussion. Section three focuses on the theoretical consideration of the concept of employer-employee relations. Section four presents results and discussions, while section five brings the study to conclusion.

\section{Literature Review}

\subsection{Human relations approach to organization}

The concept of employer-employee relations can be attributed to Mayo's Hawthorne Experiments (1927-1932). The research was focused on the behaviors of employees and their cooperation with employers in achieving production capacity. According to Tonwe (2009:167), Mayo (1880-1949) who was considered one of the pioneers of the human relations approach to an organization made a novel attempt to have a clearer understanding of the problems of industrial labor from an approach different from the scientific management thought. Priyali (2016) pointed out that contrary to the scientific management approach to organizations, Mayo's research studies postulated that organizations are not only a techno-economic part but a psycho-social organization. Employees are not to be viewed and treated like economic men who are only motivated by money, but their inter-personal relationships, employer's attitude, social and other psychological needs of the employees plays a critical influencing role. Crainer (1998:111) attributed the importance of the Hawthorne experiment to organizational behavior, he asserted that the studies revealed that improved motivation and performance in organizations were depended on the behavior and attitude of employers.

The Hawthorne Experiments influenced the quest for further research studies by a behavioral scientist on the behavior of employees in the workplace. According to Priyali (2016:7), these human relations experts integrated psychology and sociology with management and held the view that the success of the organization was hinged on the quality of the relationship between employers and the employees in the organization.

\subsection{Concept of employer-employee relations}

The growth and development of the human relations approach to an organization have attracted several scholarly works on the relationship between employers and employees in organizations in this modern time. Employer-employee relations have been regarded as complex, due to its definition. Some scholars share the perspective of employee relations as being dealings between employers and trade unions. Employer-employee relations should not be limited alone to the broad spectrum of labor relations. According to Karen (2015:104), employer-employee relations is also about the relationship with employees. Michael (2006) emphasized that employee relations practices are not restricted only to formal processes, rules, and procedures and communication channel instituted in the organization, but 
that they are those informal interactions carried out daily between the employers and the employees, without the framework of employment policies, but acting based on their initiative.

Employee relations is the existence of an interconnection between the employers and the employees in the organization. Bajaj, Sinha \& Tiwari (2013:91) pointed out that effective employeremployee relations are geared towards stimulating motivation, commitment, and trust in the employees. It also creates an organizational climate that ensures the full maximization of the potential of the employees for the optimum realization of the goals of the organization. The issue of building trust is at the center stage of human relations. Sanders $(2012 ; 2)$ posit that effective employer-employee relations elicit trust and that it is expressed when a manager exhibit consistent positive behavior regarding the discharge of official responsibilities and the show of interest towards the general wellbeing of the employees. Karen $(2015 ; 103)$ added that employer-employee relations enhance mutual respect. It is about how an employer gains the respect of the employees. Employees may not be in tandem with every decision an employer may make, but due to the strong relationship that exists, they will respect such decision.

Hogos \& Shimels $(2018 ; 68)$ succinctly assert that effective employer-employee relations set the framework for the integration of the needs of the employees into the objectives of the organization. Within the framework of employee relations, Shanks $(2007 ; 23)$ maintained that managers should be challenged to motivate their employees to strive towards the achievement of the goals of the organization and also motivating them to achieve their individual goals. There is the need for employers to recognize human nature that is the innate desire to be respected, valued, and recognized for competence and abilities, and also freedom over the discharge of work while dealing with the employees. The recognition of human nature will propel employees to put in their best for the organization. Maslow $(1943 ; 370)$ on the contrary shares the view that when employees are consistently disrespected and looked down upon by the employers, it instills the feeling of inadequacy and inferiority complex. This will inadvertently lead the employees to a state of dissatisfaction and possible disengagement.

\subsection{Concept of employee engagement}

Employee engagement has been described as pivotal to the successful performance of organizations. It is a huge challenge to business operations which is attracting the attention of business executives and human resources experts and increasingly, the acceptance of scholars in the field of organizational behavior (Soldati, 2007). According to Johnson $(2004 ; 1)$, the ability of managers to make their employees commit wholeheartedly with the business is going to be one of the huge battles for organizations in the future. To make or sustain their organization's profitability, employers must work hard to engage employees. (Kortmann, Gelhard, Zimmermann \& Piller, 2014). Baumruk (2006) posits that when organizations build a culture that facilitates the engagement of employees in their work, it culminates in staff the drive to go the extra mile and achieve organizational goals and objectives.

A disengaged employee does not necessarily mean he has exited from the organization. Vazirani (2007;5) revealed that there are employees who are in the employment of organizations and yet disengaged. The state of disengagement of these employees is a result of lack of motivation and dissatisfaction at work, the energy, and enthusiasm required to exert themselves to be productive is absent. Engagement exerts influence on the employee's attitude, commitment, and turnover levels and research studies have revealed a relationship with productivity to employees who are highly engaged at work.

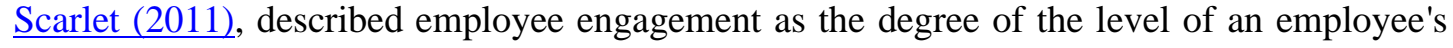
emotional attachment to the job, which can either be positive or negative. This emotion can have a strong influence on their ability to learn and discharge their duties. Catteeuw et al $(2007 ; 152)$ while citing Johnson and Johnson defined employee engagement as the degree of satisfaction employees have with their jobs, the feeling of value and the experience of trust, and cooperation in the organization. Karanges, Johnston, Beatson, and Lings (2015;130) assert that employee engagement is the willingness of employees to commit themselves emotionally and rationally to the organization.

The main focus of employee engagement is aligning the employees with the goals of the organization and willing to go the extra mile. Anitha $(2014 ; 310)$ added that the willingness of employees to exert their best efforts to organizational success and to be positive and energized reflects 
two essential factors of employee engagement. Therefore, due to their mental, physical, and emotional attachment to the organization, engaged employees are required to be more productive in the discharge of their duties. Osborne and Mohammed $(2017 ; 15)$ buttressed that a low level of employee engagement can be due to the poor employer-employee relations and the resultant effect is low productivity.

\subsection{Empowerment of employees}

Empowerment in organizations is a relational construct. The practice of empowerment is operational within the framework of effective employer-employee relations. Nassar (2017;91) posit that the idea of empowerment is based on the relationship between employers and employees. According to Aparna (2020), empowerment is the process of employers releasing to employees measures of power, authority, and freedom to make decisions concerning job-related issues. The release of authority is based on the concept of a "trust-based relationship" existing between the employer and the employee. This culminates in the employees exerting control over the work within their purview and deploying their full potential on the job.

Khadra and Ishaq, $(2018 ; 50)$ described empowerment as the process of enabling employees to exercise authority and accountability for decision making and performance of their duties. The employees take responsibility for their decisions and allow them to be "self-directed" and "selfcontrolled". To empower is to give power, unleash the hidden potential of employees, enlarge, and enrich job schedule and enhance the employee's involvement and participation in activities of the organization. Stark $(2005 ; 369)$ while eulogizing the role that empowerment play in organizations asserts that it instills in employees the feeling that they are valued, equips employees to make decisions, thereby increasing motivation. Aparna (2020;3) in his view buttress that empowerment is a mechanism that facilitates individual development and the achievement of organizational goals. Empowerment allows employees to expend quality work, hence develop an unflinching sense of devotion and a feeling of obligation to give back in consideration of the shift of power and authority.

The concept of employee empowerment in organizations is pivotal in accomplishing motivation, engagement leading to the retention of employees. Al-Haddad and Kontour $(2015 ; 236)$ reiterated that the implementation of the empowerment process on a wide spectrum within the organization promotes the achievement of success in the long run and it is the link between feeling of fulfillment and increased level of performance of the employees. Batool $(2017 ; 90)$ assert that empowerment drives employees to be committed and exerts support and loyalty to the organization. Employers exerting good leadership is imperative for the sustenance of continuous improvement of employee empowerment. According to Henry (2009;011), existing employer-employee relations stimulates the willingness of employers to tap into the intrinsic abilities of employees, reaching out to their feelings and acting as coach to inspire through training and development.

\subsection{Employee voice}

Employee voice behavior which has been regarded as one of the enablers of employee engagement is also pivotal to the effective performance of an organization (Rees, Alfes, and Gatenby, 2013). Troy (2019) asserts that employee voice is key to unleashing and maximizing human hidden potentials. Employee's creativity, innovative ability, and vigor are part of individual life, and so organizations that disregard these abilities repress them. A productive work environment requires an effective communication system between the employees and employers and organizations must provide the platform to harness these skills and characteristics. Pyman et al (2006) described employee voice as the medium through which employees freely express concern, views, and to participate and contribute to the decision-making system of the organization. Studies conducted by the Chartered Institute of Personnel Development (2017) revealed that employee voice is the means through which employees communicate suggestions to management on matters that affect them in the organization. Millward et al (2000) further reiterated that employee voice is the ability of employees to exert influence over the actions of employers.

Employee voice is a broad term that includes indirect and direct mechanisms. (Kaufman, 2015). The indirect employee voice galvanizes collective effort, such as trade unions to exert influence on a wide range of corporate-level decisions. (Lavelle, Gunnigle and McDonnel, 2010). The direct voice involves individual level- employee influencing key management decisions on matters that affect their 
day to day duties. (Jaewon, K., JohnPaul, M., and Frits, K. P., 2010). The focus here is on the unpopularexplored direct individual employee voice practices in organizations. The direct voice concept covers the provision of a platform in organizations for employees to express their discontentment and bring about the modification of the power of management. It encompasses involvement in decision-making and participation. Employee voice also recognizes the role of management in the integration of employee views with the decision- making system in the organization. According to MacLead and Clark (2012), an effective and empowered employees' voice seeks employees' views, management providing listening hear and ensuring that the views of employees are recognized and respected. Management listening skills and responsiveness to the needs of the employees, enabled by a clear communication system is a promoter of employee voice. Employee voice can be viewed as dual communication between the employer and employee, where both views are respected and have the ability to exercise influence over the managerial and operational decisions.

Empirical study has proven that employee voice has a direct relationship with engagement in an organization. According to Prucell et al (2003) research has proven that employees who feel that they have ample platform to express themselves without fear of harassment by their employers, exert a positive attitude that results in their devotion and high commitment to the organization. Kwon et al (2016) opined that employees who trust their employers to provide them the opportunity to be part of the decision-making system of the organization will put in their best and feel more engaged.

The effective employer-employee relations followed by trust and support play a crucial role in ensuring employee voice. According to Wikinson and Fay (2011) employee voice has an influencing role in the quality and performance of an organization. Farndale et al (2011) posit that research indicates a positive linkage between employee voice and other organizational behavior such as employee commitment, job satisfaction, and retention in the organization. This shows that the use of voice mechanism by employers in managerial practice facilitates fairness and trust (Guest, 2014), besides, enhances psychological construct between employers and employees. Hence, this behooves on employers to create a work climate that favors constructive voice behavior, as it may be beneficial in harnessing hidden creativity, innovation, and problem-solving in the organization.

\subsection{Improving organizational climate}

Productive employer-employee relations play a critical part in improving organizational climate. According to the Management Sciences for Health $(2005 ; 55-56)$ the manager influences the climate of an organization more than any other factor. The behavior, leading, and managing practices of the manager determines if the work climate will either be positive or negative. The findings on a survey of 2,500 organizational units in 24 organizations as presented by Buckingham and Coffman (1999) revealed that the employer is the most influencing factor in building a productive work climate. Organizational climate is a critical element of a great and comfortable work environment. Therefore, if employers can provide an enabling environment, it will enhance organizational success.

The concept of organizational climate as viewed by Haritha and Subrahmanyam $(2013 ; 13)$ is the employees' perception, attitudes, and feelings that they have about the fundamental elements of the organization, which reflects the organization's values and culture and influences their behavior either positively or negatively. Watkin and Hubbard $(2003 ; 380)$ precisely defined organizational climate as "how it feels to work in a particular environment and for a specific employer, it is also a measure of the employee's perception of those areas of that organization that impact directly on the performance of their job. Kuenzi (2008) asserts that organizational climate is a phenomenon that every organization has and it influences many facets of the organization. Organizational climate is linked with several outcomes in the work environment, like job satisfaction, employee engagement, and enhanced productivity. Climate is the perception of how an organization deals with its employers and environments, and thus emanates from factors primarily under leadership influence.

A positive climate that permeates a work environment is a booster for enhanced motivation and increases the employees' opportunity to expend adequate effort to discharge their duties. According to Schulte $(2006,146)$ research conducted has shown that an employee-climate perception and organizational climate is linked to employee engagement which has a significant influence on the employee performance, Watkin and Hubbard (2003) added that organizational climate can directly account for up to 30 percent of the variance in key organizational performance measures and that there 
are elaborate studies into the linkage between how individual employee describe their work-space and the performance success of those work environment, which strongly suggest that the more present certain organizational or leadership practices are in a given work environment, the more energized and productive workforce.

Employers play a critical role in shaping an employee's perception of organizational climate. According to Lars (2010), the influence managerial practice has on the employees is a focal point for organizational climate. The manner employers relate to their employees has a significant influence on organizational perception. This indicates that a supportive employer shows concern and interest in the general wellbeing of the employees will be stimulating a positive organizational climate than an employer who does not exhibit these behaviors.

\subsection{Relationship between employer-employee relations and employee engagement}

The effective relations between employers and employees have been regarded as crucial in enhancing employee engagement in an organization. Dulye (2006) believed that the quality of the employer-employee relationship is one of the most critical factors that drive engagement and satisfaction in organizations. Shaheen $(2017 ; 390)$ opined that employee relations focus on what level employees are engaged in the organization. This is achievable through the level of support and understanding that the employer extends to the employee. Sheaheen $(2017 ; 391)$ added that research conducted has shown that when employees feel at home in discharging their duties it instills a positive psychological behavior towards the organization, which is inevitable in fostering employee engagement level. In this vein, organizations must strive to build and nurture employee engagement, this is a twoway process through which employees are highly engaged in work and management are sensitive to the needs of their employees and making concerted efforts in meeting their needs.

A plethora of studies have shown that effective and assertive relationships are a veritable lever for employee engagement. Research conducted by CIPD (2007) revealed that the practice of managers implementing upward feedback, communication, and consultation system within the organization, treating employees fairly are factors that promote employee engagement. Cleland, Mitchinson, and Townend (2008) reported that the white paper of the Ixia Consultancy revealed that employees believed that they feel more satisfied and engaged when the relationship with their managers is based on respect and dignity. They also noted that when opportunities are availed of them to be empowered to make decisions, they feel valued, have a sense of belonging in the organization and that precipitates in engagement. Findings from the report by Kenexa Research Institute (2008) which was based on the current state of engagement globally revealed that the attitude and behavior towards employees play a key role in enhancing engagement. The report suggested that employees are engaged by managers who inspire, respect, appreciate, and creates an exciting work environment and also stimulates genuine interest in their wellbeing.

The kind of leadership style exhibited by the employer will either drive or affect negatively the level of engagement in the organization. Lloyd (2004) assert that employee engagement is depended on certain characteristics of the employer's managerial style. Macey and Schneider (2008), also held the view that the nature of the employer's leadership and management practices can have an indirect effect on the behaviors of the employees towards the organization. Lowe (2012) further postulated that employee engagement is a by-product of leadership. He asserts that engagement will improve when the leader has a direct relationship with employees. To support these assertions, research conducted by the Corporate Leadership Council (2004) on fifty thousand employees across global companies revealed that the major drivers of employee engagement are directly linked to managers. They found a high correlation between engagement and the extent of a manager's ability to communicate the goals of the organization and flexibility and adaptation to changing situations. Instituting employee engagement drivers requires employers to focus more attention on the soft aspect of the organization. This is the emotional aspect such as the positive work climate and meeting the basic psychological needs for respect, recognition, and meaning. 


\subsection{Theoretical consideration}

\section{Leader-member exchange theory}

Leader-Member Exchange Theory also called the Vertical Dyad Linkage Theory is a social relationship-based approach to leadership. The theory aids the understanding of how employers and employees achieve tasks together in the organization. (Graen \& Uhl-Bien, 1991). According to Janse (2019), this model is an assumption that leadership is made up of a dyadic (two-way) relationship that produces a connection between the employer and the employees. The existence of the quality relationship is measured by the level of respect, loyalty, support, and trust. Berrin and Tayla $(2015 ; 641)$ viewed this relationship also as a high-quality one which is characterized by the exchange of valued resources. In this relationship, leaders provide their subordinates the needed assistance, opportunities for growth and development, coaching, and other extrinsic values. The resultant effect of such resources is the motivation by the subordinates to in turn demonstrate behaviors such as dedication and loyalty. In other words, the feeling of obligation and high levels of devotion to the employer is regarded as the linkage between leader-member exchange quality and organizational behavior.

On the dyadic (two-way) relationship, the Leader-Member Exchange Theory (LMX) suggests that the onus lies on the leader to intentionally develop a relationship with each of their followers and that the quality of the relationship exerts a large influence on the performance of the followers. The theory classified employees into in-group and out-group and described how the quality of relationships affects the work-related attitudes and the behaviors of the employees in the organization. Employees in the in-group are given opportunities for personal development, added responsibilities, more attention, and greater rewards. The in-group employees are within the inner circle communication of the leader. On the other hand, the employees in the out-group are given less challenging task due to lack of trust, they have less opportunity for growth and development, they are actually outside the inner circle of the leader. The LMX theory shares the belief that the existing relationship between the leader and subordinates could yield benefits (Janse, 2019).

Sun, Chaw, Chiu, and Pan $(2013 ; 217)$ assert that research has shown a productive relationship between high leader-member exchange and high leadership effectiveness. Employers who desire a high level of performance would develop quality relationships with each subordinate in the organization. Graen and Scandura (1987) further described the dyadic relationship of having three stages, namely, role-taking, role making, and role routinization. In the role-taking, the leader assesses the skills and talents of the member and provides opportunities to express his or her capabilities in the task assigned. How the member executes the task is imperative to the development of the dyadic relationship as the leader observes the member's behavior, assessing if these actions develop the trust required to proceed to the next stage.

Role making stage affords interactions while working on the task. The development allows both the leader and the member to build a relationship that is based on trust towards the task, exchanging valuable resources to accomplish the task. According to Martin, Guillaume, Thomas, Lee, and Epitropaki (2015), the role routinization stage evolves as the role development opportunities progress. At this stage, the leader and member agree on the best approach and achieve the task. This agreement is built on trust developed from observation models behavior for both the leader and member, which leads to the anticipation of the resources needed to execute the task.

Dulebohn et al (2012) believe that the LMX theory is at the heart of achieving an organizational task. The existing relationship between the employer and employees is a determining factor for achieving high organizational performance. Ilies et al, $(2007 ; 269)$ pointed out that the quality of the relationship between employers and the employees has job implication, the previous studies conducted supporting the LMX theory has revealed that employees within-group position are highly motivated and productive at work. Therefore, employers must have a productive relationship with their employees based on strong connections. Meanwhile, lower-quality relationships will negatively affect the morale and productivity of the employees.

\section{Research methodology}

This research adopted the qualitative method for data collection. Studies and articles and a wide range of library books regarding employer-employee relations and employee engagement were relied upon for review of the literature. Keywords as shown in the abstract part of the study which helps to 
establish linkage between employer-employee relations and employee engagement were used as search terms of the relevant database. Focused interviews were conducted in generating primary data for the study.

The research was conducted in a private tertiary institution in Benin-City, Edo State, Nigeria. Benson Idahosa University was selected as a case study for this work. The sample size of this study comprised of four respondents which cut across management staff, heads of departments, and units of the University. Based on the positions they occupy, it is assumed that the respondents are better broadminded on human relations issues. The selection of these qualitative techniques emanated from the fact that they assist for better illumination of any phenomenon that may be difficult to convey.

The qualitative data generated from the research were analyzed using manual content analysis.

\section{Results and Discussion}

\subsection{Recognition of human element in the university}

The study findings gave clues in ascertaining the worth and value of employees in the University. One of the respondents reported that the University places a high premium on the staff. It was acknowledged that part of the core values which is "People Matter" shows how invaluable employees are in the University. It was revealed from the interview conducted that the University has implemented strategies designed for staff recognition and rewards for hard work. The views of the respondents give credence to the studies of Argyris (1957; 3). In his work "Personality and Organization" emphasized the personality of the individuals in the organization. He held the view that much attention should be given to the development of psychological energy, which forms the basis of human behavior. Each individual has a set of needs, and these needs release energy to get satisfaction and properly feel engaged in the organization. It is very much clear from the responses of the respondents that placing value and a high premium on the individual employees culminates in the establishment of effective employer-employee relations in an organization.

\subsection{Open door system}

As regards how the communication system operates between Management of the University and the employees. The responses from the interview indicate that the University operates an open door system where staff member's views are welcomed without fear of intimidation. The University's working climate depends on the individual at the helm of affairs. This supports the notion expressed by the Management Sciences for Health $(2005 ; 55)$. According to the report, what the employer does is the most important determinant of the organizational climate. The employer's attitude stimulates the climate, which arouses motivation. And aroused motivation is a major driver of engagement. This indicates that employers influence the work climate and play a critical role in building a productive workplace. The respondents further noted that creating a system where employees feel free to express opinions, complaints, and offer ideas and suggestions to Management enhances positive relationship that culminates in high morale and productivity. More interaction between employers and employees will stimulate productive working relations.

\subsection{Fairness and equal opportunities}

A fair assessment of employees' performance is imperative for determining the level of engagement. For instance, one of the respondents indicated that the place of fairness and equality in an organization cannot be overemphasized, since a work environment pervaded by unfair treatment and injustice contributes to poor performance. According to Mutunse (2009) employers who ensure fairness in performance assessment techniques for employees will experience a high level of engagement. Organizations that operate a policy of equal treatment for an individual employee, such will attract the employees and spur them to put in their best. Bhatla $(2011 ; 2)$ added that employers which strive to provide equal opportunities for career advancement to all employees promote levels of engagement and employees will not feel discriminated in any way in the organization. For instance, it was noted by a respondent that there is always a likelihood for rancor and bitterness to spring up in a system where a junior staff is appointed to head an office over a senior colleague in the University. This action as reported will not only create a situation where the senior staff will feel ill-treated and uncomfortable, but will also make him/her not to cooperate with such staff in the line of duties. 
To support the assertion, one of the respondents noted that when employees perceive unfair treatment, inequality, and injustice on the side of employers, it culminates into a resulting change in attitude and a decline in performance. Besides, the work climate will be tensed and that may result in employees performing at their lowest ebb.

\subsection{Appreciation and recognition}

Recognition of employees has been recognized as a critical tool for the sustainability of workforce engagement (Brick, 2012). A respondent indicated that appreciating employees for exceptional work is a fundamental human need. When employees are appreciated and recognized, they feel valued and satisfied with the job and motivated to deliver high performance. To support the responses, Avey, Wernsing, and Palanski (2012) assert that recognizing competent employees results in the converging of group dynamics to create a sense of ownership of the work environment. One of the respondents argued that recognizing the potential of employees and appropriately utilizing them, makes the employees feel needed and important. It was suggested that competent employees should be openly commended to instill a sense of satisfaction and accomplishment in him/her. Saks (2006) while emphasizing the need for recognition, noted that employees will be more likely to be engaged to the extent that they receive some level of recognition, which can be in the form of a commendation letter on the job performance.

A respondent noted that bosses should strive to work towards recognizing the work of their staff and appreciating them. A boss cannot be able to accomplish anything without the contributions and input of the people working for him. Vazirani (2007) also extolled the need for employers to develop an appreciation and recognition systems and certain benefits to improve levels of engagement in the organization. It is clear from the responses that an employee will feel a sense of attachment to the organization and level of satisfaction when recognized for competence.

\subsection{Building employer-employee relations based on trust}

The place of mutual respect between employers and employees is fundamental in fostering flourishing relationships. According to Yukl (2012) employers have been proven to exert more influence on employees when they treat them with respect and foster positive teamwork in a non conflicting manner. A report of Kenexa Research Institute (2008) also revealed that employees feel engaged when the employer respect and inspires confidence in them. A respondent from the University reiterated that the relationship between employers and employees should be based on respect and not "Master/Slave Relationship". Bosses who treat their subordinates with disdain and make them feel inadequate, inadvertently, create an unhealthy situation where employees are under stress, some develop high blood pressure, and feel frustrated coming to work. Stallard $(2007 ; 12)$ acknowledged that when employers show respect to their employees they become stirred up. They feel enthusiastic to devote extra effort to the job. Being regularly disregarded results in damaging the employees' sense of self-worth and eventually becoming disengaged.

Also, it was reported by a respondent that there are cases where bosses may lose the respect of the employees on the account of inefficiency on the job. The boss should be able to know and perform the job of the subordinates so that he/she can supervise properly and also earn their respect and trust. This supports the assumption made by Luthans and Peterson (2002). In their research of 170 supervisors and their subordinates, it was found that a boss' capability on the job can enhance the level of engagement and productivity of their subordinates, also increasing the level of confidence in their leadership.

Maslow $(1943 ; 389)$ buttressed that the needs for self-respect and the esteem of others are human psychological needs and that the satisfaction of these needs in the workplace leads to feelings of confidence, adequacy of being capable to perform, and self- worth, One of the respondent also assert that there was the need for bosses to be sensitive to the needs of their subordinates, respect should not be demanded, instead, it should flow from the boss's positive behavior and attitude.

The bottom line is that respect plays a critical part in fostering healthy employer-employee relations. Employees who are respected are enthusiastic, energetic, and open-minded and share information that will aid in decision making. The openness of ideas that emanates in a trusting, cooperative workplace makes employees creative and innovative. 


\subsection{Staff retention in the university}

Effective employer-employee relations play a crucial part in the enhancement of staff retention in the organization. Responses from the focused interview assert that apart from extreme cases where employees leave an organization for "greener pastures", when the working environment is conducive, void of intimidation and harassment, there is the tendency that staff will remain and build his/her career. The more an employee is satisfied with the working environment the possibility of them staying is higher. Employees most times leave an organization as opined by one of the respondents because they were not treated well. According to Levenson (2007) employees are more likely to stay in the organization when they are happy and satisfied in their job. BleesingWhite (2008) reported that studies have shown that 85 percent of employees who are engaged in an organization plan on staying more than 27 percent of employees who are disengaged.

For instance, one of the respondents noted that she was once offered a job opportunity in another institution, and because of the satisfaction she derived from her institution over the years, she turned it down, despite the better opportunities accrued to the offer. It was asserted that it is not all about the financial incentive provided by the organization, it is creating a positive work environment where staff members feel valued, respected, and genuinely satisfied with their job. It is imperative because an employees' drive to perform effectively is largely influenced by the kind of environment created by the organization. In this light, Towers $(2003 ; 11)$ opines that the kind of relationship that exists in an organization plays a critical role in engagement and also in managing employee retention.

\subsection{Barriers to effective employer-employee relations in the organization}

As part of the objective of the study, the researcher sought to investigate the barriers of effective human relations at the University. Interview results show that despite the cordial and positive working relationship existing in the University, there is still some measure of poor relations exhibited by a few bosses. They characterized the barriers to effective relations exhibited by some bosses amongst others on a deep sense of insecurity and character of the individual boss.

\subsubsection{Sense of insecurity}

It was opined by one of the respondents that a deep sense of insecurity exhibited by some bosses may be accounted for as a barrier to effective relations. This is attributed to a lack of self-confidence. An insecure boss may feel threatened by smarter and intelligent employees. They see them as a direct threat to their position. They jealously guard their position by exerting control over the employees. However, any form of suggestions or ideas brought forward by these outstanding employees comes to them as a challenge to their authority. It is in this light that insecure bosses would prefer to have average subordinates working for them.

Liane (2017) recounted that the worst set of bosses to work for are those who are insecure. Insecure bosses degrade the organization by hiring employees who are weak, who they thought they can control. The survey showed that insecure bosses are quick to yell and micromanage their employees without provocation. This is apparent when the employee is competent. Another respondent noted that how the insecure bosses treat and handle their subordinates has a bearing on their productivity as well as their morale. Camarote (2016) added that a boss' level of insecurity culminates in contempt for their subordinates, and principally, the needs of the organization. Insecure bosses are also opined to place huge demand and demoralize their employees at work.

\subsubsection{The character of the boss}

A respondent attributed poor employer-employee relations to the individual character of some bosses. The environment was identified as an influencing factor that shapes one's behavior. The place one lives, his association, day to day life experiences, family background, and the community at large influences one's personality. An environment one emanated might be toxic and unpleasant and may impact negatively on the character of the individual. The individual thereafter carries these negative traits along to the workplace. To support the assertion, Miksen (2020) reiterated that an organization is made up of people with negative or positive behaviors. An employee's behavior in most cases is usually a reflection of the boss's attitude and the negative attitude of a boss can lead employees to be cynical 
and handle their tasks with carelessness.

\section{Conclusion and Recommendation}

This study has revealed that implementing virile employee engagement techniques is pivotal to achieving organizational success. Enhanced employee engagement is a by-product of employeremployee relations and the quality of the relationship is one of the most critical factors that drive engagement and satisfaction of employees. The findings of this research indicate that building effectiveemployee relations in an organization entails having and demonstrating fairness and respect for employees, building trust, and having concern for the wellbeing of the employees. This confirms the Leader-Member Exchange (LMX) theory which viewed leadership as a dyadic (two-way) relationship that produces a connection between employer and employees, and the existence of a quality relationship is measured by the level of respect, loyalty, support, and trust. Most importantly, it was deduced from the study that a work environment where employees are empowered, employee voice encouraged and a favorable work climate stimulates engagement of employees. Improving employee engagement strategies is crucial for the profitability of an organization. Conversely, employees that are disengaged will result in decreased performance and negatively affecting the success of the organization. Based on the findings emanated from the study, recommendations on how to improve employer-employee relations for enhanced employee engagement are being proffered.

In building positive employer-employee relations employers should first realize the psychological components of the human resources. Employees are not just employed with relevant skills and capacities, but rather a whole person. They come along with individual challenges, lifelong experiences, and prejudices. Employees make up the emotional aspect of the organization, they respond to psychological needs for respect, recognition, belonging, growth, and meaning. (Stallard, 2007;xx). Therefore, employers must focus on creating the right environment for these human needs to be met.

Secondly, employers should understand that developing employee engagement entails a twoway relationship and a high level of commitment between employers and employees. Therefore, they must seek to build a work climate where people are free to express their concerns, views, and have open and honest communication in all aspects of the organization.

Employers should strive to instill confidence in employees by empowering them to make decisions concerning the discharge of their duties and also adopt a collaborative management style. They should also show genuine responsibility especially in terms of their well-being.

Employers should exhibit fairness in the assessment of employees' performance. Equal opportunities for career growth and advancement should be pursued vigorously as this will go a long way to eliminate the feeling of discrimination and rejection on the part of the employees. Conclusively, it is potent to note from the study that a productive working employer-employee relationship could create opportunities to attract and retain employees in an organization. Employees would prefer working for any organization whose work climate is based on mutual respect, the value of trust, and zero tolerance for harassment or workplace bully.

\section{Limitation and study forward}

The challenge was the inadequate number of respondents interviewed due to time constraints. Further research using qualitative data is recommended to understand the correlation between employeremployee relations and employee engagement in a Public Tertiary institution in Edo State.

\section{References}

Al-Hadad, S., \& Kotnour, T. (2015). "Integrating the organizational change literature; a model for successful change". Journal of Organizational Change Movement. 28( 2), 234-262.

Anitha, J. (2014). Determinants of employee engagement and their impact on employee Performance. International Journal of Productivity and Performance Management, 63, 308323. Doi:10.1108/ijppm-01-2013-0008.

Aparna, J. (2020). Employee empowerment. Retrieved from: https://www.economicsdiscussionnet/human-resource-management/employeeempowernment/31827

Argyris, Chris (1957). Personality and organization. New York: Harper and Row. 
Avey, J.B., Wernsing. T.S. \& Palanski, M.E. (2012). Exploring the process of ethical leadership: The mediating rule of employee voice and psychological ownership. Journal of Business Ethics, 07, 21-34. doi: 10.1007/s10551-012-1298-2.

Batool, B.A. (2017). The impact of employee empowerment on the success of organizational change. A study in private enterprise in Jordan. Journal in Public Administration and Governance,7(1), 87-101. doi: 10.5296/jpag.v7i1.10849URL

Bajaj, R. Sinha, S. \& Tiwari, V. (2013). Crucial factors of human resources management for good relations: A case study. International Journal of Mining, Metallurgy and Mechanical Engineering, 1(2), 90-92.

Baumruk, R. (2006). "Why manager are crucial to increasing engagement: Strategic HR Review. January/February.

Berrin, E. \& Talya N. B. (2015). Leader-member exchange theory. International Encyclopedia of the Social and Behavioural Sciences ( $2^{\text {nd }}$ ed., pp.641-647) http//dx.doi.org/10.1016/B978-008.097086-822010-2.

Bhatla, N. (2011). To study the employee engagement practices and its effect on employee performance with special reference to Kiki and HDFC bank in Luknow. International Journal of Scientific and Engineering Research, 2(8) 1-7.

Blessing White (2008), The State of Employee Engagement, BlessingWhite

Brick, W. P. (2012). Employee recognition programs critical to workplace culture. The Public Manager, Retrieved from: https/www.td.org/publication/magazines/the-public-

manager/Archives/2012/winter/Employee-Recognition-Programs. December 14.

Buckingham, M. \& Goffman, Curt (1999).First break all the rules: What the world's greatest managers do differently. New York: Simon and Schuster, in Managers who lead (2005). A Handbook for Improving Health Sciences: Management Sciences for Health. RA 971.M3463

Camarote R. (2016), Seven ways to tell if your boss is insecure. Retrieved from: $\mathrm{https//www.inc.com/robbin-camarote}$

Catteeuw, F. Flynn E,. \& Vonderhorst J. (2007).' Employee engagement; boosting productivity in turbulent times. Organizational Development Journal, 25(2), 151-157.

Chand, Smriti (2016) Human relations: Conflict, nature and factors affecting human relations. Retrieved from: https://www.yourarticlelibrary.com

Chartered Institute of Personnel Development (2017). The future of employee voice. Retrieved from: https://www.cipd.co.uk/knowledge/work/future-voice

CIPD (2007). Employee engagement. Retrieved from: http//www.cipd.co.uk/subjects/empreltns/general/enpengnt.htm?isrchRes=1

Cleland, A, Mitchinson W, Townend A. (2008). Engagement assertiveness and business Performance-A New Perspectives, Ixia Consultancy Ltd.

Corporate Leadership Council (2004). Driving performance and retention through employee engagement, Corporate Executive Board in Stallard, M.L. (2007). Fired up or burned out, how to reignite your team's passion, creativity and productivity. USA: Thomas Nelson.

Crainer, S. (1998). Key management ideas; Thinkers that changed the management world $\left(3^{\text {rd }}\right.$ ed.). Financial Times, Prentice Hall.

Dulebohn, J. H., Bommer, W. H., Liden, R.C., Brouer, R. L. \& Ferris, G. R. (2012). A meteanalysis of antecedent and consequences of leader-member exchange: Integrating the past with an eye toward the future. Journal of Management. 38(6), 1715-1759, doi: $10.1177 / 0149206311415280$.

Dulye and Co (2006). 5 ways to keep new hires engaged. Retrieved from;http//www.imdulye.com Farndale, E. Van, R. J., Kelliher, C. \& Hope H.V. (2011) "The influence of perceived employee voice on organizational commitment: an exchange perspective." Human Resource Management, 50(1), 43-129.

Graen, G. B. \& Scandura, T.A. (1987). Toward a psychological of dyadic organizing. Research in organizational Behaviour 9, 175-208. Retrieved from: http.//www.researchgate.net/profile/Terri_scandura/publication/232576635.

Graen, G. B. \& Uhl-Bien (1991). Partnership-making applies equally well to team-mate sponsor, 
teammate-competence, network and teammate-teammate relationships. Journal of Management Systems, 3(3), 49-54.

Guest, D. (2014)." Employee engagement a skeptical analysis". Journal of Organizational Effectiveness: People and Performance. 1(2). 141-156.

Haritha, K. \& Subrahmanyam S.E.V. (2013) Organizational climate: An empirical investigation in Penna Cement Industries Ltd. Nigeria Journal of Business and Management Invention. 2(2), $12-20$.

Henry, O. (2009). Managing behind the scene. A view point on employee empowerment. Africa Journal of Business Management, 3(1), 009-015.

Hogos, B. \& Shimels, Z. (2018). A literature review on the effects of employee relations on improving employee performance. International Journal in Management and Social Science. 16(4), 6676

IIies, R., Nahrgang, J.D. \& Morgeson, F. P. (2007). Leader-member exchange and citizenship behaviors: a meta-analysis. Journal of Applied Psychology, 92(1), 269.

Jaewon, K, John Paul, M, \& Frits, K. P. (2010) Employee voice and organizational performance: Term versus representative influence. Human Relations, 63(3), 371-394. Doi: $10.1177 / 0018726709348936$.

Janse, B. (2019). Leader-member exchange theory (LMX), Retrieved July 20, from toolshero.https//www.tooshero.com/management/leader-member-exchnage-theory-imx/

Johnson, M. (2004). The new rules of engagement: life-work balance and employee commitment, The Chartered Institute of Personnel and Development.

Karanges, E. Johnston, K. Beatson, A. \& Lings I. (2015). The influence of internal communication on employee engagement: A Pilot Study, Public Relations Review, 41, 129131. Doi: 10: 1016/j.Pubrev.2014./2.003.

Karen A. Y. (2015). Stop knocking on my door. Charleston, South Carolin: Advantage.

Kaufman, B, E, (2015). Theorizing determinants of employee voice. An integrative model across discipline and levels of analysis. Human Resources Management Journal, 25(1), 19-40.

Kenexa (2008). Engaging the employee: A Kenexa Research Institute World Trends Report. Kenexa Research Institute.

Khadra, D. \& Ishaq H. (2018). Successful employee empowerment; major determinants in the Jordain context. Eurasian Journal of Business and Economics, 11(21) 46-68.

Kotmann, S. Gelhard, C., Zimmermann, C. \& Piller F. (2014). Linkages strategies flexibility and operational efficiency: The mediating role of ambidextrous operational capabilities. Journal of Operations Management, 32, 475-490. Doi: 10.1016/jijom.201.09.007.

Kwon, B. Farndale, E. \& Park, J.G. (2016). "Employee voice and work engagement; macro, meso and micro level drivers of convergence?" Human Resource Management Review. 26. (4), $327-337$.

Kuenzi, M. (2008). An integrated model of work climate, University of Central Florida: Orlando.

Lars, P. (2010). Organizational climate and performance, The relation between organizational climate and performance and an investigation of the antecedent of organizational climate. The thesis of Deift University of Technology.

Lavella, J. Gunnigle P. \& McDonnel A. (2010) Patterning employee voice in multinational companies. Human Relations. 63(3), 393-416.

Levinson E (2007), Developing High Employee Engagement Makes Good Business Sense. Retrieved from:

www.interactionassociates.com/ideas/2007/05/developing high employee engagement mak es good_business_sense.php_

Liane D. (2017). The scariest, most anxiety-provoking bosses to work for-and how to cope. Retrieved from: https//www.qz.com

Lloyd, M. (2004). Driving performance and retention through employee engagement. Retrieved from: https//www.lloydmorgan.com/PDF/driving\%20performance\%20and\%20retention.

Lowe, G. (2012). How employee engagement matters for hospital performance. Health Care Quarterly 15, 29-39. Doi: 10.12927/hca.2012-22915.

Luthans F, Peterson SJ (2002), 'Employee engagement and manager self- efficacy: implications for 
managerial effectiveness and development', Journal of Management Development, 21(5), 376387.

Macey, WH, Schneider, B. (2008), 'Engaged in engagement: we are delighted we did it', Industrial and Organizational Psychology, 1, 76-83.

MacLead, D. \& Clark, N. (2012). Engaging for success: enhancing performance through employee engagement. Retrieved from: http.//www.bis.gov.uk/files/52215.pdf

Management Science for Health (2005). Managers who lead, A handbook for Improving Health Services. USA, Cambridge.

Martin, R, Guillaume, Y. Thomas G. Lee, A. \& Epitropaki (2015). Leader-member exchange (LMX) and performance. A meta-analytic review. Personal Psychology of Financial Marketing, 7(2), 178.

Mary, Kay Ash (2008). http.//www./itera.co.uk/NDKIMDA/.

Mayo, E. (n.d). Business and management: Elton Mayo. Retrieved from: https//www.bl.uk/people/elton-mayo.

Maslow, A. H. (1943). A theory of human motivation, Psychological Review, 50(4), 370-396.

Miksen, C. (2020). How the behavior of company managers can affect the behavior of their subordinates. https//www.smallbusiness.chron.com

Millward, N. Bryn, A. \& Forth J. (2000). All change at work? Rout.

Mutunse, C. N. (2009). Factors that contribute to the level of employee engagement in the telecommunication industry in Kenya: A case study of Zain, Kenya. (Master's thesis University of Nairobi). Retrieved from https.//www.erepositoryuoribi.ac.kc/bitstream/handle/11290/12682/full\%20tex.pdf.

Nassar, M. A. (2017). Psychological empowerment and organizational change among hotel employers in Egypt. Research in Hospital Management. 7(2), 91-98.

Osborne, S. \& Mohamad S. H. (2017). Effective employee engagement in the workplace. Journal of Applied Management and Technology, 16(1), 50-67.

Priyali, S. (2016).Elton mayo's human relations approach to management. Retrieved From: http://www.yourarticlelibrary.com

Prucell, J. Kinnie, N. Hutchinson, S. Rayton, B. \& Swart, J. (2003). Understanding the people and performance link: Unlocking the Black Box, London: CIPD.

Pyman, A. Cooper, B. Teicher J., and Holland (2006). A comparison of the effectiveness of employee voice arrangement in Australia. Industrial Relations Journal, 37, 543-559.

Rees, C. Alfes, K. \& Gatenby, M. (2013). "Employee voice and engagement: Connections and consequences". The International Journal of Human Resource Management, 24(14), 27802798.

Saks, A. M. (2006). Antecedents and consequence of employee engagement. Journal of Managerial Psychology, 21(7), 600-619. doi: 10.1108/02683940610690169.

Sanders, D. (2012). .Placing trust in employee engagement, employment relations. A CAS Council. Retrieved from http://www.macas.org.UK/media/pdf/1/2.

Scarlet, K. (2011).What is Employee Engagement? Retrieved from: http://www.scarletsurvey.com/papers-and-studies/whitepapers/

Schreiner, E. (2009). What is the employer-employee relationship? Retrieved from: https//www.smallbusiness.chron.com/employer-employee-relationship-16737

Schulte, M. O. (2006). Organizational climate systems and psychological climate perceptions: A cross-level study of climate-satisfaction relationships. Journal of Occupational and Organizational Psychology, 645-671.

Shaheen, A., Fais Bin A. \& Abdul R. J. (2017). Employee engagement on employee relations with supervisor and employee performance relationship in developing economy: Critical analysis with PLS-SEM. Saudi Journal of Business and Management Studies.2 (4A), 389-398.

Shanks, N. H. \& Buchbinder S. B. (2007).Introduction to health care management, Jones and Bartlett Learning.

Sharma, M. P., Sadana, B.L. \& Harpreet K. (2013). Public administration: In theory and Practice, $\left(49^{\text {th }}\right.$ ed.). India, Kitab Mahal. 
Soldati, P. (2007). Employee engagement: What exactly is it? Retrieved from: www.managementissues.com/2007/3/8opinion/employee-engagement-what-exactly-is-it.asp.

Stallard, M.L. (2007). Fired up or burned out, how to reignite your team's passion, creativity and productivity. USA: Thomas Nelson.

Stark, J. (2005). Maturity model for pdm. Product lifecycle management: $21^{\text {st }}$ Century Paradigm for Product Realization, 367-382.

Steve Jobs (2008). http//www.wikipedia.org/wiki/image:stevejobsmacbookAirJPG

Sun, L. Chow, L. Chiu, R. \& Pan W. (2013). Outcome favorably in the link between leadermember exchange and organizational citizenship behavior: Procedural fairness climate matters. The Leadership Quarterly, 24 (1), 215-226. Doi: 10.1016/j.leaqua 2012.10.008.

Tonwe, D. A. (2009) "George Elton Mayo" in H.S Nnamdi., O.J. Offiong \& D. A. Tonwe (Eds.), Eminent Administrative and Management thinkers. (pp. 260-288). Lagos, Nigeria: Amfitop Books.

Towers, Perrin (2003), Working Today: Understanding What Drives Employee Engagement, Towers Perrin HR Services.

Troy, M. (2019), The evolution of employee voice and collaborative workplace relations. Retrieved from Griffith University website: ,https://www.blogs.griffith.edu.au/conversations-workorganization-wellbeing/2019/09/04/the-evolution-of-employee-voice-and-collaborativerelations/

Vazirani, N. (2007). Employee engagement. Working papers series (WP505), SIES College of Management Studies. Retrieved from: http://www.siescoms.edu.edu/images/pdf/research/working_paper/employee engagement.pdf

Watkin, C. Hubbard, B. (2003). Leadership motivation and the dirves of shared price: the business case for measuring organizational climate. Leadership and Organizational Development Journal. 24(7), 380-386.

Wikinson, A. \& Fay, C. (2011). "New times for employee voice" Human Resource Management, $50(1), 65-74$.

Yukl, G. A. (2012). Leadership in organizations ( $8^{\text {th }}$ ed.). Salem, OR: Prentice-Hall.

\section{Appendices}

\section{Interview Questions for Benson Idahosa University Selected Staff Members}

1. Recognition of Human Element in the University

i. Based on the human relation policy existing in the University, can you say that the University places a high premium on staff members?

ii. If yes, what are the factors that prove the above assertion?

2. Open Door System
i. Does the Management of the University operate an open door system where employees' views are welcomed?
ii. If yes, can you expatiate further, please
iii. Who influences the organizational climate in the University?

3. Fairness and Equal Opportunities
i. Do you agree that a system of fairness and equality are influencing factors of effective employer-employee relations in the University?
ii. Please can you give supportive evidence

4. Appreciation and Recognition
i. Do you agree that recognition and appreciating the hard work of employees will enhance the level of relations in the University?
ii. If yes, what are the measures put in place by the University to appreciate and recognize the good work of employees? 
5. Building Employer-Employee Relations Based on Trust

i. There is the assertion that an organizational culture based on the value of trust and mutual respect will foster positive employer-employee relations in the University. Please what is your take on the statement?

ii. Are there any indices operational in the University to support the above assertion?

6. Staff Retention in the University

Please what is your opinion about the effectiveness of employer-employee relations in enhancing staff retention in the University?

7. Barriers to effective employer-employee relation in the University

From your own opinion, what are the likely barriers to effective employer-employee relations in the University? 